REgular Article

\title{
STUDIES ON GENETIC CORRELATION AND PATH COEFFICIENT ANALYSIS OF BLACKGRAM (VIGNA MUNGO [L.] HEPPER) GENOTYPES UNDER SALINITY
}

\author{
V. A. MOHANLAL ${ }^{*}$, K. SARAVANAN, T. SABESAN
}

Abiotic Stress Laboratory, Department of Genetics and Plant Breeding, Faculty of Agriculture, Annamalai University, Annamalai Nagar 608 002, Tamil Nadu, India

\begin{abstract}
A study was carried out with twenty-one blackgram genotypes in coastal saline low land in three seasons to study the genetic correlation and path coefficient analysis. Eleven seed yield and yield contributing traits were recorded on the genotypes raised in RBD design with two replications. Based on the pooled analysis, plant height, pods per plant and yield per plant recorded high PCV and GCV value. High heritability along with genetic advance as percent of mean observed for days to first flowering, plant height, primary branches, clusters per plant, pods per plant and yield per plant. Genotypic correlation studies revealed that yield per plant had positive significant correlation with plant height, clusters per plant, pods per plant, pod length and seeds per pod. Path coefficient analysis indicated high positive direct effect of pods per plant and pod length on yield per plant in saline condition. The genotype VBG-10010 performed well under saline environment over seasons.
\end{abstract}

\section{INTRODUCTION}

Blackgram (Vigna mungo [L.] Hepper) is one among the important crop cultivated in India. It has easily digestible protein and low flatulence content. The average production in India 14 lakh tonnes and productivity $451.61 \mathrm{~kg} / \mathrm{ha}$. In Tamilnadu the average production was 1.21 lakh tonnes and productivity $354.84 \mathrm{~kg} / \mathrm{ha}$ [1].

In India, the production of blackgram is relatively low. In order to increase the production and cultivation, a quality enhancement in terms of genetic improvements is essential in blackgram. A path analysis study is important in this direction. Hence a study on genetic correlation and path coefficient analysis was taken up to decipher the interrelation between character under saline environment in blackgram.

\section{MATERIALS AND METHODS}

For this investigation, twenty-one blackgram genotypes were grown in coastal saline lowland in three seasons (2017-2018). The experiments were conducted in Randomized Block Design with two replications. Standard agronomical practices were followed to raise the crop. The mean value of two replications over seasons were used for statistical analysis. The observations were recorded for eleven quantitative characters viz., days to first flowering, plant height, primary branches, clusters per plant, pods per plant, pod length, pod weight, seeds per pod, seed size, 100 seed weight and yield per plant. Genres statistical package was used for the statistical analysis.

\begin{abstract}
RESULTS AND DISCUSSION
There were significant variations based on the pooled analysis. Phenotypic coefficient of variation (PCV) was higher than genotypic coefficient of variation (GCV) for all the characters. It showed that all the characters not only expressed by the genotype but also influenced by the environment. Similar observations were earlier reported [2-4]. High GCV was recorded by plant height, pods per plant and yield per plant. Improvement could be possible in these traits through selection. Similar results were earlier reported [3-5]. The Characters viz., days to first flowering, primary branches, clusters per plant and pod weight showed moderate GCV whereas low GCV was recorded for characters like pod length, seeds per pod, seed size and 100 seed weight. High PCV was recorded for plant height, pods per plant and yield per plant. It indicated that selection of this characters are not advisable, in early generations.
\end{abstract}

High heritability was recorded for the characters viz., days to first flowering, plant height, primary branches, clusters per plant, pods per plant, yield per plant. These findings are in agreement with earlier findings for all the characters except 100 grain weight, pod weight [4]; for yield per plant and pods per plant [6] and for clusters per plant, primary branches, plant height [7]. High heritability along with high genetic advance as percent of mean (GAM) was recorded by days to first flowering, plant height, primary branches, clusters per plant, pods per plant and yield per plant which revealed that selection could be effective for these characters.

Received 15 February 2018; Accepted 30 March 2018

*Corresponding Author

V. A. Mohanlal

Abiotic stress laboratory, Department of Genetics and Plant Breeding, Faculty of Agriculture, Annamalai University, Annamalai Nagar 608 002, Tamil Nadu, India

Email: mohanlalo6o6@gmail.com

( This article is open access and licensed under the terms of the Creative Commons Attribution License (http://creativecommons.org/licenses/by/4.o/) which permits unrestricted, use, distribution and reproduction in any medium, or format for any purpose, even commercially provided the work is properly cited. Attribution - You must give appropriate credit, provide a link to the license, and indicate if changes were made. 
The correlation coefficient estimates that plant height, clusters per plant, pods per plant, pod length and seeds per pod showed significant association with yield per plant. It indicates that yield per plant was highly correlated with these independent variables. Similar results were reported in earlier findings for number of cluster per plant [3]; for clusters per plant, pod per plant [4] and for number of pods per plant [7]. Days to first flowering showed negative significant association with clusters per plant. This corroborates with the findings [4], [5]. Clusters per plant recorded positive significant association with pods per plant whereas days to first flowering shows negative significant association. Clusters per plant, pods per plant and pod length showed positive significant association with seeds per pod and days to first flowering recorded negative significant association with seeds per pod. Clusters per pod recorded negative significant with seed size.

The path coefficient analysis of different traits contributing towards yield per plant revealed that high positive effect was showed by pods per plant and pod length. Similar results were earlier reported [4], [8] and [9-11]. It showed that selection for these traits will be efficient in crop improvement. High positive direct effect was recorded by pods per plant and low positive direct effect recorded by clusters per plant. Pod weight expressed high negative direct effect while seed size expressed low negative direct effect on yield per plant. High positive indirect effect was recorded by clusters per plant on pods per plant. High negative indirect effect was showed by days to first flowering on pods per plant.

Table 1: Magnitude of variability and estimates of heritability and genetic advance for various characters in 21 blackgram genotypes for pooled analysis

\begin{tabular}{llllll}
\hline S. No. & Characters & GCV (\%) & PCV (\%) & $\mathbf{h}^{2}$ & GA as percent of mean \\
\hline 1 & Number of days to first flowering & 10.62 & 11.29 & 88.51 & 20.58 \\
2 & Plant height (cm) & 23.74 & 25.72 & 85.16 & 45.13 \\
3 & Number of primary branches & 16.49 & 17.12 & 92.78 & 32.72 \\
4 & Number of clusters per plant & 15.81 & 20.41 & 60.06 & 25.25 \\
5 & Number of pods per plant & 24.42 & 26.91 & 82.36 & 45.65 \\
6 & Pod length (cm) & 5.73 & 6.71 & 72.98 & 10.08 \\
7 & Pod weight (g) & 10.01 & 12.17 & 67.59 & 16.95 \\
8 & Number of seeds per pod & 7.26 & 9.83 & 54.48 & 11.03 \\
9 & Seed size (cm) & 5.08 & 5.32 & 91.29 & 9.99 \\
10 & 10o seed weight (g) & 9.15 & 9.82 & 86.82 & 17.56 \\
11 & Yield per plant (g) & 27.89 & 30.38 & 84.25 & 52.74 \\
\hline
\end{tabular}

Table 2: Genotypic correlation among various characters in pooled analysis

\begin{tabular}{|c|c|c|c|c|c|c|c|c|c|c|}
\hline Characters & $\mathbf{P H}$ & PB & CPP & PPP & $\mathbf{P L}$ & PW & SPP & SS & HSW & YPP \\
\hline DFF & 0.014 & -0.115 & $-0.514^{*}$ & $-0.626^{* *}$ & -0.272 & -0.457 & $-0.748^{* *}$ & 0.036 & 0.142 & -0.397 \\
\hline PH & 1.000 & 0.008 & 0.107 & 0.293 & 0.410 & -0.206 & 0.249 & 0.312 & 0.275 & $0.533^{* *}$ \\
\hline $\mathrm{PB}$ & & 1.000 & 0.111 & 0.239 & -0.564 & -0.338 & -0.216 & -0.068 & -0.281 & 0.265 \\
\hline $\mathrm{CPP}$ & & & 1.000 & $0.838^{* *}$ & 0.184 & 0.172 & $0.586^{* *}$ & $-0.444^{*}$ & -0.082 & $0.649^{* * *}$ \\
\hline PPP & & & & 1.000 & 0.368 & 0.090 & $0.820^{* *}$ & -0.268 & -0.179 & $0.826^{* * *}$ \\
\hline PL & & & & & 1.000 & 0.364 & $0.551^{* *}$ & -0.006 & 0.366 & $0.469^{*}$ \\
\hline PW & & & & & & 1.000 & 0.004 & 0.227 & 0.023 & -0.163 \\
\hline SPP & & & & & & & 1.000 & -0.380 & 0.341 & $0.832^{* * *}$ \\
\hline SS & & & & & & & & 1.000 & -0.032 & -0.268 \\
\hline HSW & & & & & & & & & 1.000 & 0.134 \\
\hline
\end{tabular}

DFF-Days to first flowering, PH-Plant height, CPP-Clusters per plant, PPP-Pods per plant, PL-Pod length, PW-Pod weight, SPP-Seeds per plant, SS-Seed size, HSW-Hundred seed weight, YPP-Yield per plant.

Table 3: Path co-efficient analysis among various characters in 21 blackgram genotypes in pooled analysis

\begin{tabular}{|c|c|c|c|c|c|c|c|c|c|c|c|}
\hline Characters & DFF & $\mathbf{P H}$ & PB & CPP & PPP & $\mathbf{P L}$ & PW & SPP & SS & HSW & YPP \\
\hline DFF & -0.1748 & 0.0013 & -0.0172 & -0.0105 & -0.4802 & -0.0918 & 0.1637 & 0.1753 & -0.0022 & 0.0391 & -0.397 \\
\hline $\mathrm{PH}$ & -0.0023 & 0.0977 & 0.0011 & 0.0021 & 0.2246 & 0.1381 & 0.0738 & -0.0582 & -0.0200 & 0.0756 & $0.533^{* *}$ \\
\hline PB & 0.0201 & 0.0007 & 0.1489 & 0.0022 & 0.1835 & -0.1899 & 0.1211 & 0.0507 & 0.0043 & -0.0773 & 0.265 \\
\hline $\mathrm{CPP}$ & 0.0898 & 0.0104 & 0.0165 & 0.0204 & 0.6430 & 0.0617 & -0.0617 & -0.1374 & 0.0285 & -0.0225 & $0.649^{*-*}$ \\
\hline PPP & 0.1093 & 0.0285 & 0.0356 & 0.0171 & 0.7676 & 0.1241 & -0.0322 & -0.1921 & 0.0172 & -0.0491 & $0.826^{* *}$ \\
\hline PL & 0.0476 & 0.0400 & -0.0839 & 0.0037 & 0.2828 & 0.3369 & -0.1302 & -0.1290 & 0.0004 & 0.1008 & $0.469^{*}$ \\
\hline PW & 0.0799 & -0.0201 & -0.0503 & 0.0035 & 0.0689 & 0.1224 & -0.3582 & -0.0009 & -0.0145 & 0.0063 & -0.163 \\
\hline SPP & 0.1308 & 0.0243 & -0.0322 & 0.0119 & 0.6290 & 0.1855 & -0.0014 & -0.2344 & 0.0244 & 0.0940 & $0.832^{* * *}$ \\
\hline SS & -0.0062 & 0.0305 & -0.0101 & -0.0090 & -0.2057 & -0.0021 & -0.0812 & 0.0891 & -0.0642 & -0.0087 & -0.268 \\
\hline HSW & -0.0248 & 0.0268 & -0.0418 & -0.0016 & -0.1370 & 0.1233 & -0.0082 & -0.0800 & 0.0020 & 0.2754 & 0.134 \\
\hline
\end{tabular}

RESIDUAL EFFECT $=.3407227$, DFF-Days to first flowering, PH-Plant height, CPP-Clusters per plant, PPP-Pods per plant, PL-Pod length, PW-Pod weight, SPP-Seeds per plant, SS-Seed size, HSW-Hundred seed weight, YPP-Yield per plant. 


\section{REFERENCES}

1. Anonymous 2018. www.agropedia.iitk.ac.in. last visited on 28.02.2018.

2. Meshram, M. P., R. I. Ali, A. N Patil, and M. Sunita, M. 2013. Variabilty studiesin M3 generation in blackgram (Vigna mungo [L] Hepper). The bioscan 8: 1357-1361.

3. Geethanjali, K. 2015. Variabilty and characterization of blackgram (Vigna mungo [L] Hepper) for yellow mosaic virus resistance. Professor Jayashankar Telaungana State Agricultural University Rajendranagar, Hyberabad.

4. Punitha, E. 2017. 'Studies on genetic divergence in blackgram (Vigna mungo [L] Hepper) using microsatellite markers". M. Sc., Thesis, Annamalai University.

5. Rambabu, E. 2016. "Identification of molecular markers linked to yellow mosaic virus resistance in blackgram (Vigna mungo [L] Hepper)." M. Sc., thesis,Professor Jayashankar Telangana State Agricultural University.

6. Sowmini, K. and P. Jayamani. 2013. Genetic variability studies for yield and its component traits in RIL population of blackgram (Vigna mungo [L]
Hepper). Electronic Journal of Plant Breeding, 4: 1050-1055.

7. Suresh, S., S, Jebaraj and S. Arulselvi. 2013. Genetic variability, correlation and path analysis for yield and yield attributing traits in mutant populations of mungbean (Vigna radiata [L.] Wilzek). International Journal of Scientific Research, 2:10.

8. Nagarjuna sagar, M and M. Reddy sekhar. 2001. Character association studies in blackgram (Vigna mungo [L] Hepper). Madras Agricultural Journal, 88(4-6): 222-224.

9. Pushpa, R. Y., Y. Koteswara rao, Y. Satish and J. Sateesh Babu. 2013. Estimates of genetic parameters and path analysis in blackgram (Vigna mungo [L] Hepper). International Journal of Plant, Animal and Environmental Sciences, 3:4.

10. Mandal. B. Asit., and N. D. Majumder. 2014. Genetic divergence, heritability and genetic advance in blackgram (Vigna mungo [L] Hepper). J. Andaman Science Association., 19:9-13.

11. Panigrahi. K. K., A. Mohanty and B. Baisakh. 2014. Genetic divergence, variability and character association in landraces of blackgram (Vigna mungo [L] Hepper) from odisha. J. Crop and Weed., 12;155165 . 